\title{
НОТАРИАЛЬНОЕ УДОСТОВЕРЕНИЕ МЕДИАТИВНОГО СОГЛАШЕНИЯ
}

\section{NOTARY CERTIFICATE OF THE MEDIATIVE AGREEMENT}

\section{E. Shashkina} G. Shvyrev

Summary: The article considers the regulatory and legal regulation of notarial certification of a mediation agreement, which is the result of a conciliation procedure with the participation of a mediator. Special attention is paid to the procedure for notarizing the said agreement. The role of the notary in giving the mediative agreement the force of the executive document is also considered.

Keywords: mediator, notary, mediation agreement, mediation.

\author{
Шашкина Елена Анатольевна \\ Аспирант, ФГБОУ ВО «Юго-Западный государственный \\ университет» (2. Курск) \\ KSTUcivillaw@yandex.ru \\ Швырев Герман Сергеевич \\ Преподаватель, ФГБОУ ВО «Юго-Западный \\ государственный университет» (2. Курск) \\ german14@mail.ru
}

Аннотация: В статье рассматривается нормативно-правовое регулирование нотариального удостоверения медиативного соглашения, которое является результатом проведения примирительной процедуры с участием посредника - медиатора. Особое внимание уделяется самой процедуре нотариального удостоверения указанного соглашения. Также рассматривается роль нотариуса в придании медиативному соглашению силы исполнительного документа.

Ключевые слова: медиатор, нотариус, медиативное соглашение, медиация.
$\Pi$ роцедура медиации как способ урегулирования споров при помощи медиатора на основе добровольного согласия сторон в нашей стране применяется конфликтующими сторонами не так часто, поскольку законодательное закрепление указанной процедуры осуществилось относительно недавно, а именно принятием в 2010 году Федерального закона № 193-Ф3 «О6 альтернативной процедуре урегулирования споров с участием посредника (процедуре медиации)» (далее - Закон о медиации). При этом в последнее время процедура урегулирования споров с участием посредника применяется к самым разнообразным конфликтам. Экономические, семейные и иные взаимоотношения сторон могут приводить к возникновению конфликтов. Процедура медиации является действенным способом разрешения возникших, или возможных разногласий [1. C. 46].

С целью минимизации судебных споров и мирного урегулирования споров, а также большего распространения медиации, в юридической литературе высказываются мнения по поводу включения процедуры медиации в различные сферы.

Так, например, Е.И. Химикус указывает на необходимость активного внедрения указанной процедуры в наследование в целом и в наследование обязательной доли в частности. В связи с этим автор предлагает на законодательном уровне закрепить обязанность нотариуса разъяснять наследникам право обращения к процедуре медиации, для того чтобы по ее итогам была возможность заключить медиативное соглашение, которое признавалось бы обязательным для нотариуса. Это способствует решению спорных ситуации без обращения в суд, а также сохранению нормальных дружеских отношений между наследниками[2].

Некоторые авторы предлагают, включит обязательную процедуру медиации в семейные правоотношения.

Так, например, И.А. Трофимец полагает, что введение института обязательной семейной медиации, позволит В некоторых случаях сохранить брак, а в остальных будет способствовать сглаживанию негативных последствий распада семьи [3].

B.В. Измайлов, также утверждает, что в настоящее время есть объективная потребность в обсуждении варианта обязательного применения медиации при расторжении брака в суде, когда один из супругов против развода [4].

Тем не менее, стоит согласиться с мнением Ю.А. Зайцевой, которая отмечает, что проведение процедуры медиации не должно быть обязательным, а супруги должны самостоятельно определиться, обращаться к медиатору или нет. При этом указанный автор считает целесообразным, чтобы супруги обращались к нотариусу при заключении медиативного соглашения. Не стоит забывать, что супруги могут заключить, например, соглашение о разделе общего имущества, брачный договор, соглашение об уплате алиментов. Форма таких согла- 
шений письменная, и при этом требуется нотариальное удостоверение [5].

Логическим завершением проведенной процедуры медиации является подписание сторонами медиативного соглашения. Данный документ должен содержать сведения о сторонах, предмете спора, проведенной процедуре медиации, медиаторе, а также согласованные сторонами обязательства, условия и сроки их выполнения. В нем стороны принимают обязательства совершить какие-либо действия по разрешению своего спора [6].

Сведения о сторонах и медиаторе указываются в соответствии с правилами их индивидуализации. Кроме того, в литературе отмечается, что многосубъектность характерна не только для материальных гражданских правоотношений, но и процедурных. Практически это приводит к тому, что медиаторов в процедуре медиации может быть несколько. Могут возникнуть довольно замысловатые комбинации:

1. в материальном правоотношении существует несколько кредиторов, и у каждого имеется медиатор;

2. в материальном правоотношении участвует несколько должников, и у каждого имеется медиатор;

3. в материальном правоотношении участвует один должник и один кредитор, но у должника или кредитора или у обоих имеется несколько медиаторов [7].

Под предметом спора в данном случае понимаются гражданско-правовые разногласия, возникшие между сторонами, и отражающие их оценки и суждения по юридическим фактам и действительным правоотношениям между ними [7].

Что касается формы заключения медиативного соглашения, то по общему правилу оно заключается в простой письменной форме. Согласно п.2 ст. 12 Закона о медиации оно подлежит исполнению на основе принципов добровольности и добросовестности сторон. При этом, на практике возникают соответствующие проблемы, связанные с исполнением тех положений, которые были достигнуты сторонами в процессе разрешения конфликта и закрепленные в медиативном соглашении.

Самсонов Н.В., Самсонов В.Н. отмечали, что существенным препятствием к широкому использованию медиации в отечественной правоприменительной практике является проблема недостаточной исполнимости внесудебных медиативных соглашений [8].

Возникает вопрос, какими средствами придать большую силу непосредственно самому медиативному соглашению?
С 25.10.2019 года вступило в силу положение о том, что нотариально удостоверенные медиативные соглашения или их нотариально засвидетельствованные копии являются исполнительными документами, на основании которых судебный пристав-исполнитель может возбуждать исполнительное производство (ч. 1 ст. 12 Федерального закона от 02.10.2007 № 229-Ф3 «О6 исполнительном производстве»). Соответствующие изменения были также внесены в Ф3 от 27.07.2010 № 193-Ф3 «Об альтернативной процедуре урегулирования споров с участием посредника (процедуре медиации)» и в «Основы законодательства Российской Федерации о нотариате» (утв. ВС РФ 11.02.1993 № 4462-1). Такая процедура может стать востребованной для участников исполнительного производства [9].

Как указывает Т. Кочанова это совершенно новый для действующего в настоящее время процессуального законодательства вид исполнительного документа [10].

Нотариус при удостоверении медиативного соглашения указывает в нем сведения об участвовавшем в проведении примирительной процедуре медиаторе. Кроме того, данное лицо должно в обязательном порядке должно присутствовать при удостоверении между сторонами медиативного соглашения, а в случае, если в соответствии с соглашением сторон было предусмотрено участие нескольких посредников, то при удостоверении медиативного соглашения должен присутствовать как минимум один из медиаторов, проводивший примирительную процедуру между сторонами.

Исходя из общих правил удостоверения сделок, нотариус обязан разъяснить сторонам и медиатору (медиаторам) смысл и значение представленного ими проекта сделки и проверить, соответствует ли его содержание действительным намерениям сторон и не противоречит ли требованиям закона (ст. 54 Основ законодательства РФ о нотариате).

Кроме того, важным с точки зрения участников процесса медиации является то обстоятельство, что проведение медиации означает для нотариуса одновременно оказание участникам соглашения квалифицированной юридической помощи [11].

Е.А. Иванова отмечает, что, несмотря на некоторые проблемные моменты, которые могут возникнуть при утверждении нотариусами медиативных соглашений, возможность их нотариального удостоверения и придание им силы исполнительного документа могут сыграть позитивную роль в развитии юридической практики и популяризации процедуры медиации среди граждан и юридического сообщества [12].

В настоящее время удостоверение нотариусами ме- 
диативного соглашения маловостребованно не практике. Возможно, это связано с недавним закреплением в законодательстве положений о возможности нотариального удостоверения указанных соглашений и придания им силы исполнительного документа. Основываясь на изменениях в законодательстве, а также анализируя мнения авторов можно прийти к выводу о том, что активное взаимодействие медиаторов и нотариусов позволит обеспечить устойчивое исполнение медиативных соглашений, придав им дополнительные правовые гарантии, а также поможет облегчить работу судейского аппарата.

\section{ЛИТЕРАТУРА}

1. Сурков А.Н., Шашкина Е.А., Швырев Г.С. Процедура медиации в Российской Федерации // Известия Юго-Западного государственного университета. Серия история и право. 2019. № 4. С. 44-50.

2. Химикус Е.И. Заключение медиативного соглашения при наследовании обязательной доли // Современное право [Электронный ресурс]. 2017. № 12. СПС «КонсультантПлюс»: поиск по источнику опубликования.

3. Трофимец И.А. Роль адвоката и медиатора в бракоразводном процессе // Семейное и жилищное право. 2015. № 1. СПС «КонсультантПлюс»: поиск по источнику опубликования.

4. Измайлов В.В. Применение процедуры медиации при расторжении брака // Юстиция [Электронный ресурс]. 2018. № 1. СПС «КонсультантПлюс»: поиск по источнику опубликования.

5. Зайцева Ю.А. Реализация права супругов на заключение медиативного соглашения // Законы России: опыт, анализ, практика [Электронный ресурс]. 2018. № 1. СПС «КонсультантПлюс»: поиск по источнику опубликования.

6. Соколова Е.П. Комментарий к Письму Минфина России от 20.05.2019 № 03-11-11/35989 «Медиаторы и УСН: возможно ли?» // Нормативные акты для бухгалтера [Электронный ресурс]. 2019. № 13. СПС «КонсультантПлюс»: поиск по источнику опубликования.

7. Пешкова (Белогорцева) Х.В., Кашурин И.Н., Макаров 0.В., Поваров Ю.С., Ротко С.В., Беляев М.А., Тимошенко Д.А., Чиришьян А.Р. Комментарий к Основам законодательства Российской Федерации о нотариате.

8. Самсонов Н.В., Самсонов В.Н. Проблема исполнимости медиативных соглашений // Арбитражный и гражданский процесс [Электронный ресурс]. 2016. № 2. СПС «КонсультантПлюс»: поиск по источнику опубликования.

9. Иванова Е.А. Соглашения в сфере гражданской юрисдикции: процессуально-правовой аспект. Статут, 2020. 180 с.

10. Кочанова Т. Примирительные процедуры как перспективный вариант разрешения спора // Административное право [Электронный ресурс]. 2019. № 4. СПС «КонсультантПлюс»: поиск по источнику опубликования.

11. Ярков В.В. Медиация в нотариальной деятельности: новые возможности и их пределы // Нотариус [Электронный ресурс]. 2020 № 1. СПС «КонсультантПлюс»: поиск по источнику опубликования.

12. Иванова Е.А. Новейшее регулирование института медиативного соглашения в Российской Федерации: нотариальное утверждение // Нотариус [Электронный ресурс]. 2020. № 1. СПС «КонсультантПлюс»: поиск по источнику опубликования.

( Шашкина Елена Анатольевна (KSTUcivillaw@yandex.ru ), Швырев Герман Сергеевич (german14@mail.ru ).

Журнал «Современная наука: актуальные проблемы теории и практики» 